\title{
PESAN IKLAN DALAM MEMBANGUN MEREK
}

\author{
Rahmat Saleh* \\ rama.etnies.rs@gmail.com
}

\begin{abstract}
The world of advertising in the competition to expose a brand at present is very tough. Therefore, it is necessary to have efforts and strategies to win the competition. The advertising message has an important role to build a brand in that a message consistency will build the customer mind for a brand. This article will discuss how the advertising message is managed through consistent actions to be able to build a brand image. The method undertaken in compiling this scientific article is the observation of bottled tea drink advertising. The repetitive and continuing message will be a structured pattern to leave a memory in the customer mind in that brand awareness will be stronger in the customer memory for a brand which is the capital in building a strong brand.
\end{abstract}

Keywords: advertising message, message consistency, brand awareness.

\section{Pendahuluan}

Di era digital saat ini di mana arus informasi yang semakin deras dan mudah diakses, banyak sekali pesan-pesan iklan dari berbagai merek yang berlalu lalang baik di media konvensional maupun di media digital. Pesan iklan yang muncul ini seringkali tidak dapat menarik perhatian para audiensnya. Pesan iklan yang ditayangkan tersebut akan lewat begitu saja dan tidak memberikan ingatan apa pun kepada audiensnya. Hal ini juga dampak dari semakin banyaknya iklan yang berseliweran dan berusaha masuk ke ingatan audiens. Dengan semakin banyaknya iklan maka audiens tidak mampu mengenali atau mengingat satu persatu iklan yang dipaparkan kepadanya.

Ramainya iklan bisa dilihat pada perang iklan dari salah satu industri. Misalkan industri minuman teh kemasan yang pada akhir-akhir ini iklannya paling rajin muncul di televisi.

Menurut Nielsen Advertising Information Services, Teh Pucuk Harum merupakan produsen teh dengan belanja iklan terbesar di media cetak dan televisi pada 2016. Nilainya mencapai $\mathrm{Rp} 381,7$ miliar meningkat 26 persen dari tahun sebelumnya.

Diperingkat kedua, Teh Gelas produksi

* Dosen Program Studi Manajemen Pemasaran Politeknik Ubaya, Surabaya 
dari Orang Tua Group mencatat belanja iklan Rp 359,6 miliar sepanjang 2016, naik 2 persen dari tahun sebelumnya. Di urutan ketiga, Frestea merek teh kemasan produksi Coca-Cola ini mengucurkan dana promosi Rp 298,7 miliar, melonjak lebih dari 10 kali lipat dibanding tahun sebelumnya.

Dilihat dari Gambar 1, data anggaran belanja iklan pada tahun 2016 menunjukkan betapa agresifnya perusahaan teh kemasan dalam melakukan iklan. Bisa dibayangkan sangat ramainya iklan minuman teh yang dipaparkan ke audiens. Audiens yang terpapar berbagai iklan akan sulit mengingat atau membedakan iklan. Pertanyaan yang paling penting harus dijawab jika melihat kondisi ini adalah bagaimana caranya membuat ingatan yang kuat dari iklan yang disampaikan ke audiens.
Membuat ingatan konsumen akan merek adalah modal di dalam membangun merek. Misalkan ketika pelanggan mempertimbangkan untuk menyukai sebuah merek minuman ringan sebagai tujuan yang kemudian membutuhkan ingatan atau informasi mengenai segala hal tentang minuman ringan.

Berikut dapat dilihat data AMDK (Air Minum Dalam Kemasan) yang paling banyak dikenal berdasarkan hasil top brand indek di bawah (Tabel 1) ini.

Dari Tabel 1 dapat dilihat hasil Top Brand Index merek Aqua sebesar 75,9\%. Hal ini menunjukkan adanya kekuatan merek pada Air Minum Dalam Kemasan (AMDK) Aqua.

Ingatan konsumen akan berperan penting dalam membangun kekuatan merek.

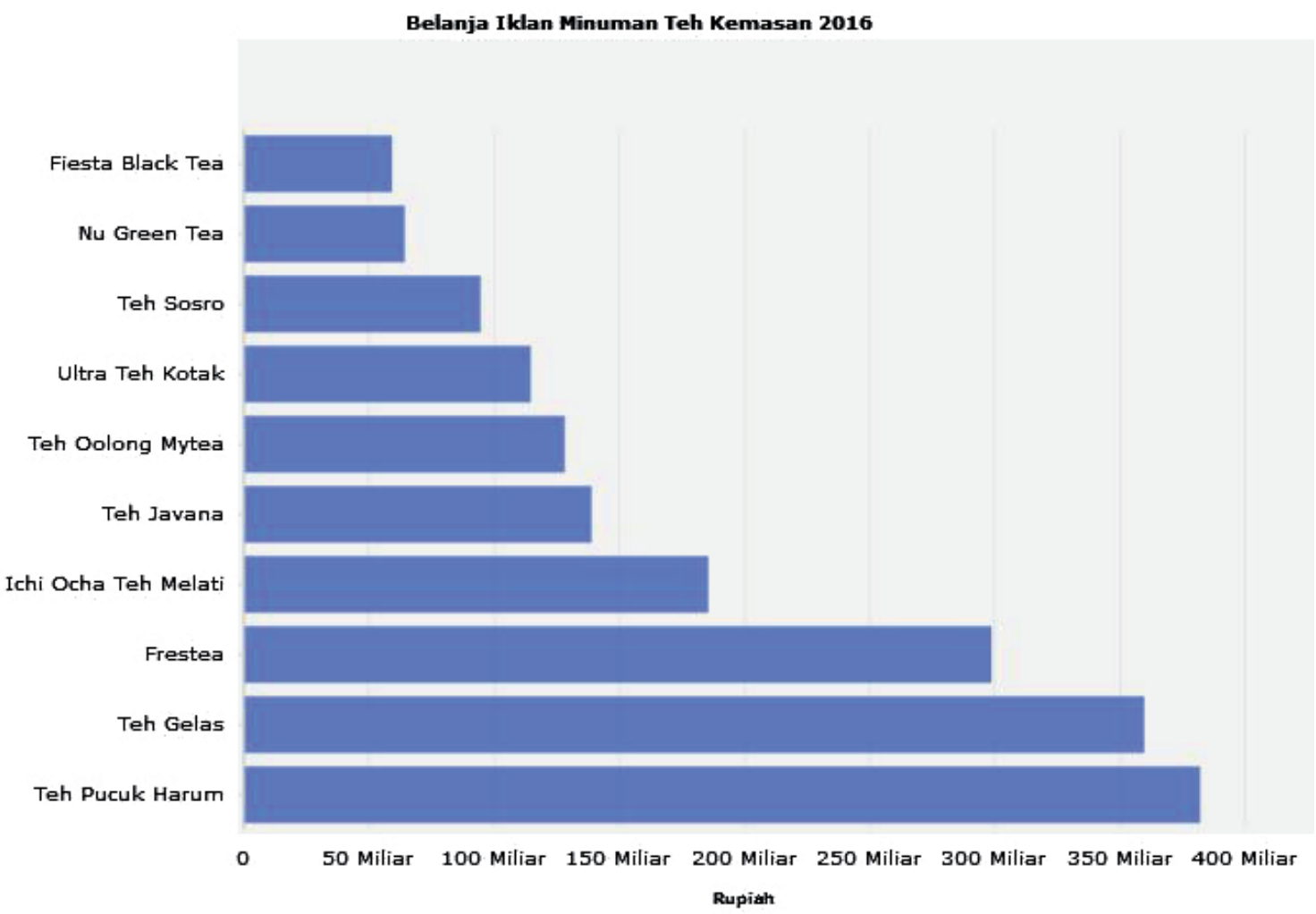

Gambar: Data Belanja Iklan Minuman Teh 2016

Sumber: Databoks, Katadata Indonesia 
Berbagai upaya periklanan yang dilakukan oleh perusahaan adalah sebagai usaha dalam membangun sebuah merek.

Dari data belanja iklan produk teh kemasan menunjukkan bahwa perusahaan teh saling berlomba melakukan belanja iklan. Yang tentunya output dari hasil periklanan tersebut salah satunya adalah agar mereknya dikenal (mempunyai merek yang kuat). Selain itu dari data merek AMDK yang paling dikenal menunjukkan bahwa perusahaan berlomba dalam membangun mereknya yang kuat. Sehingga dari kedua data di atas menunjukkan bahwa perusahaan berhasrat besar untuk melakukan periklanan dan menjadikan mereknya sebagai merek yang paling kuat.

\section{Iklan}

Iklan adalah bagian dari bauran promosi, dan bauran promosi adalah bagian dari bauran pemasaran. Secara sederhana iklan didefinisikan sebagai pesan yang menawarkan suatu produk yang ditujukan kepada masyarakat lewat suatu media (Kasali, 1995). Iklan merupakan suatu pesan persuasif untuk komunikasi pemasaran atau komunikasi publik tentang sesuatu produk (barang, jasa, atau ide) yang disampaikan melalui media, dibiayai oleh pemrakarsa serta ditujukan kepada sebagian atau seluruh masyarakat. Iklan juga sebagai bentuk komunikasi massa, di mana iklan terjadi bukan melalui proses tatap muka sebagaimana komunikasi interpersonal.
Iklan sebagai sebuah teks adalah sistem tanda yang terorganisir menurut kode-kode yang merefleksikan nilai-niai tertentu, sikap, dan juga keyakinan tertentu. Setiap pesan dalam iklan memiliki dua makna, yaitu makna yang dinyatakan secara eksplisit di permukaan, dan makna yang dikemukakan secara implisit di balik permukaan tampilan iklan.

Junaedi (2013: 110) menjelaskan bahwa komponen-komponen dalam definisitentang iklan yaitu:

a. Suatu bentuk komunikasi. Secara aktual, iklan dibentuk dengan sangat terstruktur dari komunikasi verbal maupun nonverbal yang disusun untuk memenuhi format waktu dan ruang yang spesifik yang ditentukan oleh pihak sponsor.

b. Iklan diarahkan pada kelompok khalayak dan bukan ditujukan pada individu tertentu. Dikarenakan tujuan yang lebih mengarah pada kelompok inilah iklan lebih bersifat nonpersonal atau merupakan bentuk dari komunikasi massa.

Junaedi (2013:111) mengungkapkan bahwa "Iklan harus menggunakan medium untuk mencapai khalayak. Medium iklan adalah media yang dibayar oleh pemasang iklan untuk meletakan iklannya sehingga mampu menjangkau khalayak luas. Dari medium inilah dikenal berbagai bentuk iklan yang digunakan, seperti iklan radio, televisi, koran, iklan luar ruang, dan sebagainya".

Tabel 1. Top Brand Index Kategori Air Minum Dalam Kemasan

\begin{tabular}{|cccc|}
\hline No & Brand & Top Brand Index 2014 & Top Brand Index 2014 \\
\hline $\mathbf{1}$ & AQUA & $75.2 \%$ & $75.9 \%$ \\
\hline $\mathbf{2}$ & CLUB & $3.4 \%$ & $5.0 \%$ \\
\hline $\mathbf{3}$ & VIT & $3.2 \%$ & $2.6 \%$ \\
\hline $\mathbf{4}$ & ADES & $2.2 \%$ & $2.6 \%$ \\
\hline
\end{tabular}

Sumber : www.topbrand-award.com 


\section{Pesan Iklan}

Dalam dunia periklanan pesan yang disampaikan dalam iklan sangatlah penting dalam pencapaian tujuan iklan yang dimaksud. Pemasang iklan harus memperhitungkan apa yang harus disampaikan agar mendapat tanggapan sesuai dengan yang diinginkan. Pesan iklan adalah apa yang direncanakan perusahaan untuk disampaikan dalam iklannya dan bagaimana perencanaan penyampaian pesan itu secara verbal dan nonverbal" (Sumartono, 2002:14). Sedangkan menurut Bovee (1996: 141) pesan iklan adalah ide atau berita yang dikomunikasikan atau yang disampaikan kepada audiens melalui media iklan.

Adapun yang harus diperhatikan dalam penyusunan pesan iklan adalah:

1. Isi pesan. Komunikator harus memperhitungkan apa yang harus disampaikan kepada khalayak sasaran supaya mendapat tanggapan yang diinginkan. Dalam menentukan isi pesan yang baik, perlu adanya daya tarik yang unik, yaitu: (a) Daya tarik rasional untuk membangkitkan kepentingan diri audiens yang menunjukkan bahwa produk tersebut akan menghasilkan manfaat yang dikatakan; (b) Daya tarik emosional untuk membangkitkan emosi positif atau negatif yang akan memotivasi audiens. Daya tarik emosional yang positif seperti humor, cinta, dan kebahagiaan. Daya tarik emosional negatif seperti rasa takut, rasa bersalah, dan malu; (c) Daya tarik moral lebih diarahkan pada perasaan audiens tentang apa yang benar dan apa yang baik. Daya tarik moral sering dipakai untuk mendukung masalah-masalah sosial.

2. Struktur pesan. Keefektifan suatu pesan tergantung pada struktur dan isinya. Struktur iklan yang baik adalah dapat memberi pernyataan dan membiarkan pembaca dan pemirsa menarik kesimpulan sendiri.
3. Format pesan. Format pesan yang dibuat komunikator harus mencolok. Bila disiarkan melalui televisi maka semua elemen tersebut ditambah dengan bahasa tubuh (isyarat nonverbal) yang direncanakan.

4. Sumber pesan. Dampak pesan yang dirasakan oleh khalayak juga dipengaruhi oleh penerimaan khalayak terhadap pengirim pesan. Pesan-pesan yang berasal dari sumber terpercaya lebih persuasif sifatnya. Adapun tiga faktor yang memengaruhi kredibilitas sumber pesan, yaitu: (a) keahlihan, merupakan suatu pengetahuan khusus yang nampak dimili oleh komunikator yang mendukung pesan yang disampaikan; (b) sifat terpercaya, dihubungkan khalayak dengan seberapa objektif dan jujurnya sumber tersebut menurut khalayak; serta (c) sifat disukai, merupakan daya tarik sumber pesan di mata khalayak.

\section{Pesan Konsisten}

Integrated Marketing Communication (IMC) menganjurkan bahwa koordinasi pesan merek, dari sumber apa pun, harus konsisten untuk memastikan citra merek (Duncan dan Moriarty, 1998; Madhavaram et al, 2005). Mengacu pada IMC, konsistensi merupakan semua kegiatan komunikasi harus bertindak dalam rencana yang sama dengan suara yang unik, satu pesan, dan satu tujuan untuk menawarkan konsistensi dalam komunikasi (Duncan dan Caywood, 1996).

Beberapa studi pada efek pesan yang sama menyarankan adanya efek positif pada pengolahan pikiran konsumen dan pengayaan informasi ketika orang terkena pesan melalui eksekusi bervariasi dan berbeda yang bertentangan dengan pesan yang sama (Grass and Wallace, 1969; McCullough dan Ostrom, 1974 ). Selanjutnya, eksekusi pesan yang berbeda bahkan dapat 
merangsang konsumen dan membuat mereka berpikir.

Kesimpulan yang sama diamati ketika orang terkena pesan yang konsisten datang dari berbagai sumber di mana mereka dihadapkan ke pesan yang sama dari sumber yang berbeda. Sekali lagi, setiap opsi komunikasi merupakan konteks yang berbeda dari penyajian pesan (Chang dan Thorson, 2004; Edell dan Keller, 1989).

\section{Ekuitas Merek}

Menurut Kotler dan Keller (2009: 334), ekuitas merek adalah seperangkat aset dan liabilitas merek yang berkaitan dengan suatu merek, nama dan simbolnya yang menambah atau mengurangi nilai yang diberikan oleh suatu barang atau jasa kepada perusahaan atau pelanggan perusahaan. Shimp (2004: 10) menyatakan, ekuitas merek dari perspektif konsumen, sebuah merek memiliki ekuitas sebesar pengenalan konsumen atas merek tersebut dan menyimpannya dalam memori mereka beserta asosiasi merek yang mendukung, kuat, dan unik. Ekuitas merek dalam perspektif konsumen terdiri atas dua pengetahuan tentang kesadaran merek dan citra merek.

Brand equity tidak terjadi dengan sendirinya tetapi ditunjang oleh elemen-elemen pembentuk brand equity (Simamora, 2001) yaitu:

1. Brand Awareness (Kesadaran Merek);

2. Brand Asociation (Asosiasi Merek);

3. Perceived Quality (Persepsi Kualitas) ;

4. Brand Loyalty (Loyalitas Merek);

5. Other Proprietary Brand Assets (Aset-aset Merek lainnya).

\section{Asosiasi Merek}

Menurut (Widjaja, 2007 : 121), asosiasi merek merupakan hal-hal lain yang penting dalam asosiasi merek adalah asosiasi yang menunjukkan fakta bahwa produk dapat digunakan untuk mengekspresikan gaya hidup, kelas sosial, dan peran profesional atau yang dapat mengekspresikan asosiasiasosiasi yang memerlukan aplikasi produk dan tipe-tipe orang yang menggunakan produk tersebut, dan toko yang menjual produk atau wiraniaganya.

Menurut Aaker (1997:160), brand association adalah segala hal yang berkaitan dengan ingatan mengenai merek. Asosiasi merek merupakan sekumpulan keterkaitan dari sebuah merek pada saat pelanggan mengingat sebuah merek. Keterkaitan tersebut berupa asosiasi terhadap beberapa hal dikarenakan informasi yang disampaikan kepada pelanggan melalui atribut produk, organisasi, personalitas, simbol, ataupun komunikasi yang disampaikan (Aaker, 1991).

\section{Kesadaran Merek}

Menurut Aaker (1991) dalam Tjiptono (2005: 40), kesadaran merek adalah kemampuan konsumen untuk mengenali atau mengingat kembali bahwa suatu merek merupakan bagian dari kategori produk tertentu. Sedangkan menurut Durianto dkk dalam Kartono (2007: 15), kesadaran merek merupakan kesanggupan seorang calon pembeli untuk mengenali, dan mengingat kembali suatu merek sebagai bagian suatu kategori produk tertentu.

Menurut Tjiptono (2005), kesadaran merek adalah kemampuan konsumen untuk mengenali atau mengingat bahwa sebuah merek merupakan anggota dari kategori produk tertentu. Menurut Aaker, brand awareness adalah ukuran kekuatan eksistensi merek dibenak pelanggan. Brand awareness mencakup: (1) brand recognition (merek yang pernah diketahui pelanggan); (2) brand recall (merek yang pernah diingat pelanggan untuk suatu kategori produk tertentu); (3) top of mind (merek pertama apa yang disebut oleh pelanggan sebagai 
salah satu kategori produk tertentu); hingga (4) dominant brand (satu-satunya merek yang diingat pelanggan).

Berdasarkan definisi di atas dapat disimpulkan bahwa kesadaran merek adalah kesanggupan seorang calon pembeli untuk mengenali atau mengingat kembali suatu merek sebagai bagian dari suatu kategori peroduk tertentu.

Kesadaran (awareness) tentang merek menggambarkan keberadaan merekdidalam pikiran konsumen, yang dapat menjadi penentu dalam beberapa kategori dan biasanya mempunyai peranan kunci dalam brand equity. Meningkatkan kesadaran adalah suatu mekanisme untuk memperluas pasar merek. Kesadaran juga memengaruhi persepsi dan tingkah laku. Kesadaran merek merupakan key of brand asset atau kunci pembuka untuk masuk ke elemen lainnya.

\section{Pembahasan}

Pembahasan akan difokuskan pada tiga hal, yakni: konsistensi pesan iklan, ingatan merek, dan implikasi pada merek.

\section{Konsistensi Pesan Iklan}

Untuk memberikan ingatan kepada konsumennya maka pesan iklan harus dikelola. Pengelolaan tersebut dititikebratkan pada konsistensi isi pesan mengacu dari penelitian yang dilakukan oleh Saleh (2014) yang menyebutkan, bahwa konsistensi pesan berpengaruh signifikan dalam membangun merek. Memang ada variabel lain yang memengaruhi ingatan konsumen akan sebuah iklan. Namun pada pembahasan kali ini hanya dititikberatkan kepada konsistensi isi pesan iklan. Penelitian yang dilakukan oleh Delgado et al (2012) tentang konsistensi pesan juga menunjukkan bahwa pada tingkat konsistensi pesan tertentu akan berdampak pada merek.

Konsistensi isi pesan iklan dilihat dalam dua hal yaitu: berulang dan berkelanjutan. Pertama yang dimaksud berulang adalah penayangan satu buah iklan ditayangkan secara berulang dalam satu kurun waktu tertentu. Dalam hal ini berarti pesan yang ditampilkan konsisten karena iklan yang sama ditayangkan berulang-ulang. Iklan yang ditayangkan berulang-ulang misalkan adalah sebuah iklan ditayangkan dalam sehari sampai berkali-kali tayang dan ditayangkan dalam dalam kurun waktu yang lama (berbulan-bulan). Dalam iklan minuman Teh Pucuk Harum, iklan tersebut berisi pesan bahwa minuman teh terbaik adalah yang diambil dari daun teh yang paling pucuk. Satu buah iklan yang diproduksi oleh Teh Pucuk Harum ditayangkan berkali-kali dalam sehari. Bahkan ditayangkan dalam waktu berbulan-bulan. Hal ini dibuktikan dari data belanja iklan minuman teh tahun 2016 yang tertinggi adalah Teh Pucuk Harum. Sehingga menunjukkn Teh Pucuk Harum yang paling sering melakukan iklan.

Kedua yang dimaksud dengan berkelanjutan adalah pembuatan iklan pertama, kedua, ketiga, dan seterusnya (iklan yang berbeda) tetap dengan pesan iklan yang sama (konsisten) yang ditayangkan selanjutnya sampai pada masa yang akan datang. Dalam iklan Teh Pucuk Harum, baik iklan yang diproduksi pertama, kedua, maupun yang selanjutnya tetap berisi pesan bahwa minuman teh terbaik adalah yang diambil dari daun teh yang paling pucuk. Tetap dengan isi pesan yang sama walaupun dengan eksekusi iklan yang berbeda-beda.

Dari kedua iklan berulang dan berkelanjutan yang ditunjukkan dalam iklan teh pucuk harum di atas menjelaskan adanya iklan yang konsisten.

\section{Ingatan Merek}

Dalam membangun ingatan pelanggan akan sebuah merek diperlukan untuk mengaitkan dengan asosiasi tertentu. Asosiasi 
akan membantu pelanggan untuk membangun ingatan tentang merek. Asosiasi suatu merek akan lebih kuat apabila dilandasi pada banyak pengalaman atau penampakan untuk mengkomunikasikannya. Beberapa kumpulan asosiasi yang dikaitkan dengan sebuah merek akan menimbulkan persepsi berupa pandangan citra (image) konsumen terhadap merek tersebut.

Dalam hal ini setiap pelanggan akan berpikir lebih mendalam lagi berkenaan dengan produk yang diinformasikan dan berhubungan pula dengan keberadaan produk terkait dengan brand knowledge untuk produk tertentu. Informasi yang bersumber dari pesan iklan menjadi modal dalam membangun pengetahuan tentang merek. Dalam iklan Teh Pucuk Harum yang konsisten mengkomunikasikan mengenai teh terbaik ada di daun teh yang paling pucuk menimbulkan asosiasi bagi konsumen bahwa Teh Pucuk Harum adalah teh dari daun yang paling pucuk.

Dengan memiliki asosiasi yag kuat maka konsumen lebih mudah mengingat tentang keberadaan merek. Sehingga kesadaran merek akan menjadi semakin kuat. Karena struktur memori konsumen tentang merek telah terbentuk sesuai asosiasi yang telah terbangun.

\section{Implikasi pada Merek}

Kekuatan merek tergantung pada upaya membangun merek yang dilakukan. Nilai kekuatan merek ini akan berubah-ubah naik atau turun tergantung pada upaya yang dilakukan. Upaya-upaya meningkatkan kekuatan merekmerupakan hal yang penting. Karena kekuatan merek yang tinggi tidak terjadi dengan sendirinya, melainkan dapat ditingkatkan dengan cara-cara tertentu. Melakukan iklan adalah salah satu upaya di dalam membangun kekuatan merek. Iklan berperan dalam menyampaikan pesan terkait merek. Dalam penyampaian pesan iklan salah satu variabel penting dalam membangun ingatan konsumen adalah pesan yang konsisten.

Gagasan tentang konsistensi juga merupakan konsep umum yang dipegang dalam literatur branding, yang menunjukkan bahwa nilai merek akan meningkat dengan komunikasi merek yang konsisten. Pesan yang konsisten akan membentuk struktur atau pola yang teratur yang selanjutnya dimasukkan ke dalam memori konsumen. Semakin teratur pola yang dibentuk maka semakin mudah masuk ke dalam memori konsumen. Upaya dalam melakukan pesan iklan berulang dan berkelanjutan dengan isi pesan yang sama adalah sebagai bentuk dalam upaya menayangkan iklan yang pada akhirnya ini adalah sebagai bentuk pesan konsisten.

Dalam mengakses memori konsumen yang telah terpapar pesan yang konsisten tersebut, konsumen akan mempunyai asosiasi terkait merek. Asosiasi ini dibentuk dari pesan-pesan yang disampaikan dalam iklan. Konsumen akan mengaitkan memorinya terkait pesan dalam iklan dengan suatu asosiasi yang unik yang membuatnya mudah diingat. Asosiasi inilah yang akan membangun ingatan tentang merek. Ingatan tentang merek merupakan bagian dalam citra merek. koordinasi pesan merek, dari sumber apa pun, harus konsisten untuk memastikan citra merek (Duncan dan Moriarty, 1998; Madhavaram et al, 2005). Dalam kondisi ini tentu kesadaran merek juga akan semakin kuat.

Dengan memiliki ingatan merek dan citra yang kuat maka merek akan terbangun dengan baik. Konsumen akan mengetahui keberadaan merek dan juga mampu mengidentifikasi tentang konsep merek. Dalam contoh yang telah disebutkan di atas konsumen mengetahui keberadaan merek Teh Pucuk Harum dan konsumen mampu mengidentifikasi bahwa Teh Pucuk Harum adalah teh asli yang segar diampil dari daun 
teh yang paling pucuk. Dengan demikian kekuatan merek telah terbangun dengan baik.

\section{Simpulan}

Pesan iklan memegang peranan penting dalam membangun sebuah merek. Pesan iklan yang konsisten akan dapat membangun ingatan konsumen akan merek. Pesan yang berulang dan berkelanjutan inilah yang dinamakan pesan yang konsisten. Pesan yang berulang dan berkelanjutan akan menjadi pola yang terstruktur dalam menuliskan memori di ingatan konsumen.

Dalam iklan Teh Pucuk Harum yang berisi pesan teh terbaik adalah yang diambil dari daun teh paling pucuk menunjukkan bahwa jika isi pesan iklan Teh Pucuk Harum tersebut disajikan secara berulang dan berkelanjutan dengan isi pesan yang sama maka akan menimbulkan ingatan kepada konsumen bahwa Teh Pucuk Harum adalah teh yang paling segar. Dengan ingatan yang sudah terbentuk tersebut maka kesadaran merek semakin meningkat. Pada akhirnya merek Teh Pucuk Raum pun semakin kuat.

Dari pembahasan di atas menjadikan konsistensi pesan sebagai variabel penting di dalam membangun sebuah merek. Karena dengan membangun merek akan membantu konsumen dalam mengidentifikasi produk dan mengambil keputusan.

\section{Daftar Pustaka}

Aaker, D. A. 1997. Manajemen Ekuitas Merek. Penerjemah: Aris Ananda. Jakarta: Mitra Utama.

Kotler dan Keller. 2009. Manajemen Pemasaran. Jilid I. Edisi ke-13. Jakarta: Erlangga.

Broniarczyk, S.M. and Alba, J.W. 1994. "The importance of the brand in brand extension". Journal of Marketing Research, Vol. 31, pp. 214-28.

Duncan, T.R. and Moriarty, S. 1998. "A communication-based marketing model for managing relationships". Journal of Marketing, Vol. 62, April, pp. 1-13.

Elena Delgado -Ballester, Navarro Angeles, Sicilia Marı'a. 2012. "Revitalising brands through communication messages: the role of brand familiarity European. Journal of Marketing. Vol. 46 No. 1/2, pp. 31-51.

Junaedi, Fajar. 2013. Komunikasi Politik: Teori, Aplikasi, dan Strategi di Indonesia. Yogyakarta: Mata Padi Pressindo.

Kartono. 2007. "Analisis Elemen-Elemen Ekuitas Merek Produk Minyak Pelumas Motor Merek Enduro 4T (Studi Kasus Pada Mahasiswa Universitas NegeriSemarang).Skripsi Fakultas Ekonomi, Program Sarjana Strata 1 UniversitasNegeri Semarang, Semarang.

Madhavaram, S., Badrinarayanan, V. and Mcdonald, R.E. 2005. "Integrated marketing communication (IMC) and brand identity as critical components of brand equity strategy". Journal of Advertising, Vol. 34 No. 4, pp. 69-80.

Kasali, Rhenald. 1995. Manajemen Periklanan: Konsep dan Aplikasinya di Indonesia. Jakarta: Pustaka Utama Grafiti. 
Saleh, Rahmat. 2014. "Pengaruh Konsistensi Pesan Terhadap Asosiasi Merek dan Sikap Merek dengan Variabel Keakraban Merek sebagai Moderasi”. Jurnal Ekonomi dan Bisnis, Universitas Airlangga, Vol 24. No. 1.

Sumartono. 2002. Terperangkap dalam Iklan: Meneropong Imbas Pesan Iklan Televisi. Bandung: Penerbit Alfabeta.

Tjiptono, Fandi. 2005. Pemasaran Jasa. Malang : Bayumedia.

Widjaja, A. 2007. Audit Manajemen. Jakarta: Rineka Cipta.

http://www.Topbrand-award.com.Top Brand Index 2014 fase 2: Kategori Air Minum Dalam Kemasan. Diakses peneliti pada 26 September 2015.

http://www.Topbrand-award.com. Top Brand Index 2015 fase 2: Kategori Air Minum Dalam Kemasan. Diakses peneliti pada 26 September 2015. 
